\title{
Host resistance stability to downy mildew in pearl millet and pathogenic variability in Sclerospora graminicola
}

\author{
R.P. Thakur, ${ }^{\mathrm{a}, *}$, V.P. Rao ${ }^{\mathrm{a}}$, B.M. Wu ${ }^{\mathrm{b}}$, K.V. Subbarao ${ }^{\mathrm{b}}$, H.S. Shetty ${ }^{\mathrm{c}}$, G. Singh ${ }^{\mathrm{d}}$, \\ C. Lukose ${ }^{\mathrm{e}}$, M.S. Panwar ${ }^{\mathrm{f}}$, Paco Sereme ${ }^{\mathrm{g}}$, D.E. Hess ${ }^{\mathrm{h}}$, S.C. Gupta ${ }^{\mathrm{i}}$, V.V. Dattar ${ }^{\mathrm{j}}$, \\ S. Panicker ${ }^{\mathrm{k}}$, N.B. Pawar ${ }^{1}$, G.T. Bhangale ${ }^{\mathrm{m}}$, S.D. Panchbhai ${ }^{\mathrm{n}}$ \\ a International Crops Research Institute for the Semi-Arid Tropics (ICRISAT), Patancheru 502 325, Andhra Pradesh, India \\ ${ }^{\mathrm{b}}$ Department of Plant Pathology, University of California, Davis, 1636 E. Alisal Street, clo US Agricultural Research Station, Salinas, CA 93905, USA \\ ${ }^{\mathrm{c}}$ Department of Applied Botany and Biotechnology, University of Mysore, Mysore 570 006, Karnataka, India \\ ${ }^{\mathrm{d}}$ Department of Plant Pathology, ARS Durgapura, Jaipur 302 018, Rajasthan, India \\ ${ }^{\mathrm{e}}$ Millet Research Station, Jamnagar 361 006, Gujarat, India \\ ${ }^{\mathrm{f}}$ CCS Haryana Agricultural University, Hisar 125 004, Haryana, India \\ ${ }^{\mathrm{g}}$ INERA, 03 B.P. 7192, Ouagadougou, Burkina Faso \\ ${ }^{\mathrm{h}}$ ICRISAT BP 320, Bamako, Mali \\ ${ }^{\mathrm{i}}$ ICRISAT Sabo Bakin Zuwo Road, PMB 3491, Kano, Nigeria \\ ${ }^{\mathrm{j}}$ NARP Aurangabad, Paithan Road, Aurangabad 431 005, Maharasthra, India \\ ${ }^{\mathrm{k}}$ Department of Plant Pathology, TNAU, Coimbatore 641 003, Tamil Nadu, India \\ ${ }^{1}$ College of Agriculture, Pune 411 005, Maharashtra, India \\ ${ }^{\mathrm{m}}$ College of Agriculture, Dhule 424 002, Maharashtra, India \\ ${ }^{\mathrm{n}}$ Maharashtra Hybrid Seed Company, B-4, Industrial Estate, Jalna 431 203, Maharashtra, India
}

Received 24 June 2003; received in revised form 6 February 2004; accepted 10 February 2004

\begin{abstract}
Downy mildew, caused by Sclerospora graminicola, is a major pathogen of pearl millet (Pennisetum glaucum) in Asia and Africa. So development of resistant cultivars has been a major goal of national and international breeding programs. Stability of resistance in pearl millet lines developed at ICRISAT was studied through a collaborative International Pearl Millet Downy Mildew Virulence Nursery (IPMDMVN). The reactions to downy mildew of 11 pearl millet lines at 17 locations in India, Burkina Faso, Mali, Niger, and Nigeria from 1995 to 1999 were recorded. Disease incidence varied significantly among lines, locations, and years. The tested pearl millet lines exhibited significant differential resistance. Resistance in lines IP 18292, IP 18293, 700651 and P $310-17$ was most stable regardless of the location or season. Analysis of the variation in resistance also suggested that the resistance in IP 18292 and IP 18293 was variable and depended on the locations and years, while the resistance in 700651 and P $310-17$ was highly stable across locations and over years. The latter two lines could prove to be the most valuable sources of downy mildew resistance. The results also revealed significant differences in $S$. graminicola populations at different locations, with the highest disease at Bagauda (Nigeria) and Durgapura (India) and lowest from Coimbatore and Aurangabad (India). Based on the reaction of the 11 pearl millet lines, the $17 \mathrm{~S}$. graminicola populations were grouped into six putative pathotypes (undefined populations closer to races).
\end{abstract}

(C) 2004 Elsevier Ltd. All rights reserved.

Keywords: Pearl millet; Sclerospora graminicola; Stable resistance; Pathogenic variation

\section{Introduction}

Downy mildew, caused by Sclerospora graminicola (Sacc.) Schröet, is the most destructive disease of pearl

*Corresponding author. Tel.: +91-40-23296161; fax: +91-403296182.

E-mail address: r.thakur@cgiar.org (R.P. Thakur). millet (Pennisetum glaucum (L.) R. Br) in India, Burkina Faso, Chad, Mali, Nigeria, Niger, Mali, Senegal, Sudan, Tanzania and Zambia (Singh et al., 1993; Williams, 1984) causing yield loss of nearly US \$134 million (ICRISAT, 1992). Considering that resource-poor farmers grow pearl millet in the semi-arid regions of Asia and Africa, and pearl millet being the staple food for millions of people there, the impact of these losses 
becomes all the more acute. In India, the disease is particularly severe on genetically uniform single-cross $F_{1}$ hybrids than on heterogeneous open-pollinated varieties (Andrews, 1987; Hash, 1997; Thakur et al., 1999). During the past 20 years, several hybrid cultivars have succumbed to this disease and have been withdrawn from cultivation in India (Thakur and Rao, 1997; Thakur et al., 1998a, b, 1999).

Sclerospora graminicola is heterothallic and highly variable (Idris and Ball, 1984; Michelmore et al., 1982), and has thus overcome single-gene resistance in host cultivars (Williams, 1984). Variation in virulence has previously been documented for $S$. graminicola isolates from several countries (Ball, 1983; Ball et al., 1986; Bhat, 1973; Idris and Ball, 1984; Nene and Singh, 1976; Shetty and Ahmad, 1981; Singh et al., 1993; Thakur, 1995; Thakur and Rao, 1997; Thakur et al., 1999, 1992; Thakur and Shetty, 1993). Host-driven virulence selection (Thakur et al., 1992) and evolution of host-specific virulence have also been observed in the pathogen populations (Jones et al., 1995; Singh and Singh, 1987; Thakur and Rao, 1997; Thakur et al., 1999; Werder and Ball, 1992). Furthermore, variation in the virulence of single-zoospore isolates (Thakur et al., 1998a, b) and single-oospore isolates (Thakur and Shetty, 1993), and DNA polymorphisms among isolates (Sastry et al., 1995) have also been clearly documented.

A number of downy mildew resistance sources are available (Singh et al., 1997) and several are being utilized in breeding resistant hybrids. But the life span of most of these commercial hybrids is only about 5 years because of the robust genetic variability in the pathogen and rapid selection of virulence against specific host cultivars. In order to develop strategies for transfer and deployment of resistance genes, a thorough understanding of the changes in virulence (genes) in the pathogen population is important. With this objective, a collaborative International Pearl Millet Downy Mildew Virulence Nursery (IPMDMVN) was initiated in 1992 to monitor virulence patterns in $S$. graminicola populations in several major pearl millet growing countries and to identify host varieties that exhibit stable resistance across locations and years.

\section{Materials and methods}

\subsection{Pearl millet lines and nursery locations}

Eleven pearl millet lines (10 inbred lines and one $F_{1}$ hybrid) from diverse geographical origins (Cameroon, Mali, Nigeria and India) were used in this study (Table 1). These lines had exhibited variable disease reactions in repeated tests in the downy mildew nursery at ICRISAT, Patancheru and other locations in India and western Africa (Singh et al., 1993; Thakur, 1995),
Table 1

Pearl millet lines used in the International Pearl Millet Downy Mildew Virulence Nursery (IPMDMVN) 1995-1999

\begin{tabular}{lll}
\hline Line & Derived from $^{\text {a }}$ & $\begin{array}{l}\text { Country of } \\
\text { origin }\end{array}$ \\
\hline P 7-4 & IP 6118 & Cameroon \\
P 310-17 & IP 6329 & Mali \\
700651 & IP 5082 & Nigeria \\
7042 R & IP 2696 & India \\
$7042 S$ & IP 2696 & India \\
852B & (MC 103 $\times$ Serere 17B- & India \\
& 12-2)-1 & India \\
MBH 110 & Private sector hybrid & India \\
J 104S & IP 7848 & India \\
IP 18292 & D2WS. GL. Yellow & India \\
IP 18293 & BLP 1 & India \\
5141B & - & \\
\hline
\end{tabular}

MBH $110=$ a private sector $($ MAHYCO $)$ hybrid with a female parent of $834 \mathrm{~B}$ derived from Serere 10LB, an inbred line developed from Serere Composite at Punjab Agril. University.

IP 18292 (D2WS GL Yellow) Dwarf White Sheath Glossy Yellow line derived from a multiplecross involving dwarfing gene $\mathrm{d}_{2} \mathrm{~d}_{2}$ from Tifton (USA), the White Sheath trait gene wsws from IP 7626 (India), and the glossy trait gene $\mathrm{gl}_{1} \mathrm{gl}_{1}$ from IP 8275 (India).

IP 18293 (BLP 1) = Bleached Leaf Purple line derived from IP 10399 (India) $\times$ IP 10729 (Sudan).

$5141 \mathrm{~B}=$ a maintainer line from Indian National Program.

${ }^{\text {a }}$ Derivation of lines $852 \mathrm{~B}=(\mathrm{MC} 103 \times$ Serere $17 \mathrm{~B}-12-2)-1$, MC 103 (Maiwa Composite) from Nigeria and Serere 17B-12-2 from Uganda.

and thus were selected as potential differential hosts for $S$. graminicola. Seed was increased at ICRISAT, Patancheru. Sub samples of individual lines drawn from the same seed lot were distributed to collaborators at key locations in the major pearl millet growing areas. Eleven test sites were located in India (Fig. 1a), one each in Burkina Faso, Niger and Nigeria, and two in Mali (Fig. 1b). These sites represented a wide range of environments in the semi-arid tropics ranging in latitude from $11^{\circ} 10^{\prime} \mathrm{N}$ at Samaru to $29^{\circ} 10^{\prime} \mathrm{N}$ at Hisar, and longitude from $1^{\circ} 33^{\prime} \mathrm{W}$ at Kamboinse to $78^{\circ} 16^{\prime} \mathrm{W}$ at Patancheru.

\subsection{Nursery management}

At each location, the 11 pearl millet lines were planted together with one local resistant and one local susceptible line. Each line was planted in 2 rows $\times 4$-m length, and the whole set of lines was repeated twice before 1998 or three times in 1998 and 1999. Seedlings were thinned 2 weeks after emergence to maintain about 50 plants per row. At all locations downy mildew was promoted using an infector-row system of screening (Williams et al., 1981), wherein a highly susceptible line was planted in every fifth row and artificially inoculated with a sporangial suspension. High humidity was provided by perfo-irrigation to promote infection and disease development. Test rows were planted about 3 weeks later when there was more 


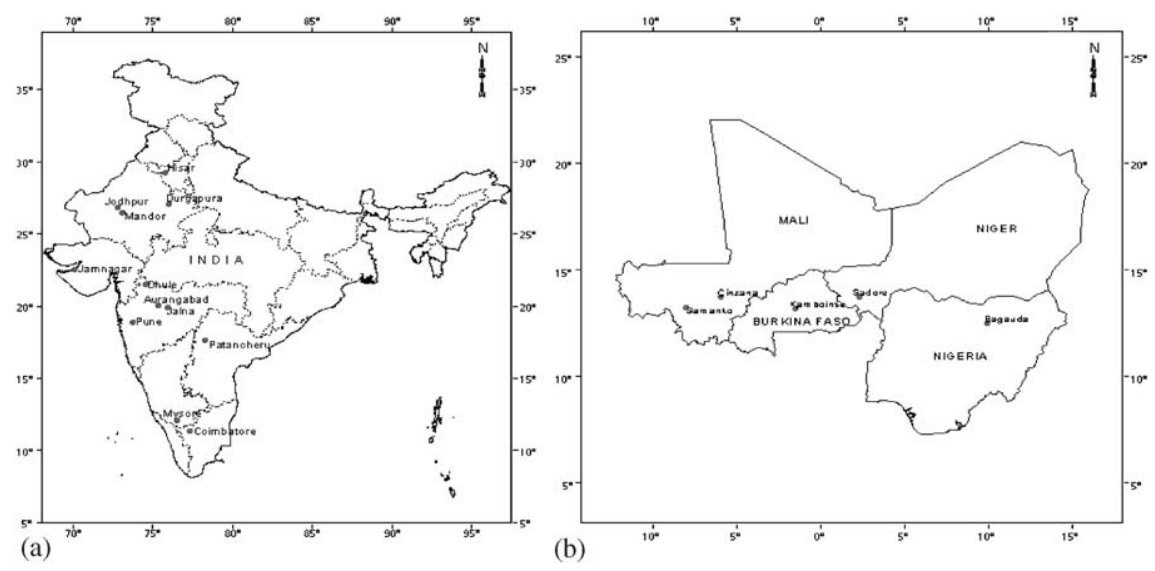

Fig. 1. Various test locations of IPMDMVN in India, Mali, Burkina Faso, Niger, and Nigeria, during 1995-1999.

than $70 \%$ downy mildew incidence in the infector rows. Perfo-mist irrigation was used at Patancheru, while other locations relied on furrow irrigation and natural rainfall. Fertilization and farming practices recommended at each location were followed. No fungicide was applied during the test periods in the nurseries. The nursery was planted during mid-June-July with the onset of the rainy season and harvested during August-September, about 90 days after planting.

\subsection{Data collection}

Diseased and total plants were counted at pre-tillering (30 days after emergence) and at the soft-dough stage (60 days after emergence) and percentage of plants infected in each line were calculated. Because number of diseased plants at the second count was greater than in the first count for some lines, the second count data were used to calculate the final disease incidence for each location and used in data analyses.

\subsection{Data analysis}

Based on a range of downy mildew incidence, lines were characterized as resistant $(0-15 \%)$, moderately resistant $(16-25 \%)$, and susceptible $(>25 \%)$. All locations, where less than 3 years of data were available, were omitted from data analyses, so data from a total of 65 environments ( 17 locations $\times 5$ years) were used in the analyses. The local resistant and susceptible control lines were different at each location, so were omitted from the analysis. General linear model procedure (SAS, 8.0 release, SAS Institute Inc., Cary, NC 27513, USA) was used to determine the effects of locations and years on downy mildew incidence. As the variation in disease incidence on a cultivar at different locations over time can be considered as an indicator for the stability of resistance in the cultivars, variation was also compared among the pearl millet lines. Because standard deviation in disease incidence is linearly related to the square root of [mean incidence $\times(1-$ mean incidence $)]$, relative variation was calculated by dividing the standard deviation with [mean incidence $\times(1-$ mean incidence $)$. Variance analysis was then conducted on the relative variation and the means were compared among the 11 pearl millet lines using a GLM procedure (SAS, 8.0 Release). Similarly, disease incidence variation among different pearl millet lines at each location and year (used as indicator of the degree of host specialization in the local pathogen population) was also analyzed to test if it changed significantly across locations and years (SAS, 8.0 release).

To characterize the pathogen population at different locations, a cluster analysis was conducted on downy mildew incidence on the tested pearl millet lines at different locations throughout the study period. First, a correlation analysis (COR procedure, SAS 8.0 release) was performed on downy mildew incidence between the differential lines. Because downy mildew incidences on some pearl millet lines were highly correlated, principal component analysis was performed to reduce the number of variables. Then the resulting 1-7 principal components over years were used in a cluster analysis to classify the pathogen population at the various test locations.

\section{Results}

\subsection{Changes in resistance of tested lines with locations and years}

Downy mildew incidence of most pearl millet lines varied greatly between locations (Table 2) and years (data not shown). Variance analysis showed that the effects of location, year, line and interactions between them were all significant $(P \leqslant 0.001)$ (Table 3$)$. Significant effects of line suggested that the 11 tested lines 
Table 2

Average downy mildew incidence ${ }^{a}$ on tested pearl millet lines at different locations during 1995-1999

\begin{tabular}{|c|c|c|c|c|c|c|c|c|c|c|c|c|}
\hline Location & P7-4 & P310-17 & 700651 & $7042 \mathrm{R}$ & $852 \mathrm{~B}$ & MBH110 & J104S & $7042 \mathrm{~S}$ & IP18292 & IP18293 & 5141B & Mean \\
\hline Aurangabad & 4.5 & 10.5 & 14.6 & 9.7 & 13.1 & 1.1 & 39.0 & 64.7 & 0.2 & 0.6 & 37.8 & 17.8 \\
\hline Bagauda & 41.2 & 14.5 & 26.4 & 99.2 & 53.0 & 33.2 & 83.1 & 98.3 & 59.6 & 68.0 & 82.0 & 59.9 \\
\hline Cinzana & 20.1 & 23.1 & 12.1 & 77.1 & 18.8 & 60.6 & 47.7 & 85.8 & 14.9 & 27.0 & 23.7 & 37.4 \\
\hline Coimbatore & 6.8 & 1.3 & 7.2 & 16.9 & 5.4 & 10.0 & 44.1 & 38.5 & 3.9 & 3.9 & 35.9 & 15.8 \\
\hline Dhule & 11.0 & 11.4 & 16.1 & 18.3 & 17.5 & 5.5 & 64.1 & 69.3 & 3.4 & 5.8 & 62.8 & 25.9 \\
\hline Durgapura & 36.3 & 18.2 & 17.2 & 66.8 & 29.0 & 23.0 & 68.0 & 94.5 & 44.6 & 25.1 & 76.7 & 45.4 \\
\hline Hisar & 6.2 & 12.3 & 5.9 & 37.9 & 11.3 & 3.7 & 53.8 & 84.9 & 0.9 & 4.7 & 5.5 & 20.6 \\
\hline Jalna & 5.8 & 4.0 & 16.2 & 26.0 & 9.2 & 89.5 & 88.9 & 73.6 & 0.6 & 3.0 & 97.4 & 37.7 \\
\hline Jamnagar & 1.0 & 5.9 & 4.7 & 58.8 & 5.9 & 0.5 & 79.2 & 71.5 & 0.0 & 0.0 & 96.4 & 29.4 \\
\hline Jodhpur & 18.6 & 17.9 & 15.1 & 24.6 & 27.7 & 6.8 & 32.5 & 34.3 & 9.2 & 16.1 & 46.5 & 22.7 \\
\hline Kamboinse & 12.4 & 15.5 & 8.7 & 57.6 & 22.0 & 47.2 & 57.0 & 72.5 & 18.7 & 14.7 & 45.9 & 33.8 \\
\hline Mandor & 16.1 & 12.0 & 18.8 & 19.3 & 20.0 & 19.0 & 59.8 & 70.9 & 14.3 & 10.3 & 40.5 & 27.4 \\
\hline Mysore & 22.9 & 16.5 & 36.2 & 21.2 & 43.1 & 8.1 & 85.1 & 89.5 & 3.9 & 5.2 & 70.8 & 36.6 \\
\hline Patancheru & 10.9 & 7.2 & 14.9 & 24.5 & 6.3 & 3.0 & 79.5 & 85.5 & 0.6 & 0.8 & 51.6 & 25.9 \\
\hline Pune & 13.7 & 10.9 & 19.0 & 23.1 & 22.0 & 1.8 & 90.5 & 85.0 & 0.4 & 2.5 & 71.1 & 30.9 \\
\hline Sadore & 42.7 & 18.3 & 7.7 & 78.4 & 46.8 & 19.9 & 36.8 & 89.8 & 40.2 & 8.9 & 77.8 & 42.5 \\
\hline Samanko & 10.4 & 27.0 & 9.8 & 73.9 & 29.5 & 36.8 & 45.3 & 77.9 & 3.1 & 23.8 & 58.3 & 36.0 \\
\hline Mean & 16.5 & 13.3 & 14.7 & 43.1 & 22.4 & 21.7 & 62.0 & 72.7 & 12.8 & 13.0 & 57.7 & \\
\hline
\end{tabular}

${ }^{\mathrm{a}}$ Percentage of plants infected.

Table 3

Variance analysis on effects of location, year, line, and their interaction for downy mildew incidence

\begin{tabular}{lrcc}
\hline Source of variation & df & Type III SS & $\operatorname{Pr}>F$ \\
\hline Location & 16 & 164366 & $<0.0001$ \\
Year & 4 & 4527 & $<0.0001$ \\
Location $\times$ Year & 44 & 95188 & $<0.0001$ \\
Line & 10 & 744051 & $<0.0001$ \\
Location $\times$ Line & 160 & 330401 & $<0.0001$ \\
Year $\times$ Line & 40 & 15990 & $<0.0001$ \\
Location $\times$ Year $\times$ Line & 440 & 164550 & $<0.0001$ \\
Error & 954 & 109241 & \\
\hline
\end{tabular}

exhibited differential resistance, and probably possess different resistance genes. The significant effects of location and year suggested that the weather conditions or the pathogen populations might have changed over years and across locations. Significant interaction between line and the other two factors suggested that virulence (frequency composition) of the local pathogen population was in all likelihood different across locations and changed over years. Among the 17 locations, Durgapura (45.4\%) in India and Bagauda in Nigeria $(59.9 \%)$ recorded the highest average downy mildew incidence on the tested pearl millet lines over the 5 years, while the mean downy mildew incidence was lowest at Coimbatore (15.8\%) and Aurangabad (17.8\%) in India (Table 4). Variance analysis of the downy mildew incidence among different lines showed that this variation changed significantly across locations and over years (data not shown). This variation was significantly greater at Bagauda than at Durgapura, and larger at Aurangabad than at Coimbatore (Table 4),
Table 4

Comparison of the pearl millet downy mildew incidence among different locations

\begin{tabular}{lll}
\hline Location & $\begin{array}{l}\text { Average } \\
\text { incidence }(\%)^{\mathrm{a}}\end{array}$ & $\begin{array}{l}\text { Relative } \\
\text { variation }\end{array}$ \\
\hline Bagauda & $59.9 \mathrm{a}$ & $0.68 \mathrm{Cd}$ \\
Durgapura & $45.4 \mathrm{~b}$ & $0.58 \mathrm{~F}$ \\
Sadore & $42.5 \mathrm{~b}$ & $0.62 \mathrm{Ef}$ \\
Jalna & $37.7 \mathrm{c}$ & $0.86 \mathrm{~A}$ \\
Cinzana & $37.4 \mathrm{c}$ & $0.65 \mathrm{de}$ \\
Mysore & $36.6 \mathrm{c}$ & $0.69 \mathrm{Cd}$ \\
Samanko & $36.0 \mathrm{~cd}$ & $0.61 \mathrm{Ef}$ \\
Kamboinse & $33.3 \mathrm{de}$ & $0.60 \mathrm{Ef}$ \\
Pune & $30.9 \mathrm{ef}$ & $0.76 \mathrm{~B}$ \\
Jamnagar & $29.5 \mathrm{fg}$ & $0.86 \mathrm{~A}$ \\
Mandor & $27.4 \mathrm{gh}$ & $0.56 \mathrm{~F}$ \\
Dhule & $25.9 \mathrm{hi}$ & $0.65 \mathrm{de}$ \\
Patancheru & $25.9 \mathrm{hi}$ & $0.76 \mathrm{~B}$ \\
Jodhpur & $22.8 \mathrm{ij}$ & $0.47 \mathrm{G}$ \\
Hisar & $20.6 \mathrm{jk}$ & $0.74 \mathrm{bc}$ \\
Aurangabad & $17.8 \mathrm{kl}$ & $0.71 \mathrm{bcd}$ \\
Coimbatore & $15.8 \mathrm{l}$ & $0.49 \mathrm{G}$ \\
\hline
\end{tabular}

${ }^{\text {a }}$ Average incidence on 11 tested lines over years.

${ }^{\mathrm{b}}$ Standard deviation of the incidence on 11 tested lines at certain locations divided by square root of [mean incidence $\times(1-$ mean incidence)].

suggesting that the pathogen population was highly host genotype-specific with high virulence on some genotypes at Bagauda and Aurangabad, but had low genotype specificity at Durgapura and Coimbatore. The differences in downy mildew incidence among different years were relatively small, although 1998 showed slightly higher (but statistically significant) disease incidence (35.9\%) over other years $(30.3-32 \%)$ (Table 5). This was 
consistent with a preliminary analysis of the weather variables (temperature, relative humidity and hours of leaf wetness), which were generally consistent over years at a location (data not shown).

Significant differences in downy mildew resistance were observed among the 11 tested pearl millet lines. In general, among the 11 pearl millet lines tested, IP 18292,

Table 5

Comparison of pearl millet downy mildew incidence in different years across locations (= pathogen populations)

\begin{tabular}{lll}
\hline Year & $\mathrm{N}^{\mathrm{a}}$ & Average incidence $(\%)^{\mathrm{b}}$ \\
\hline 1998 & 374 & $35.9 \mathrm{a}$ \\
1999 & 396 & $32.0 \mathrm{~b}$ \\
1995 & 218 & $31.7 \mathrm{~b}$ \\
1996 & 307 & $31.3 \mathrm{~b}$ \\
1997 & 374 & $30.3 \mathrm{~b}$ \\
\hline
\end{tabular}

${ }^{\text {a }} \mathrm{N}=$ line $\times$ location $\times$ replications.

${ }^{\mathrm{b}}$ Figures followed by the same letters are not significantly different according to least significant difference test $(P>0.05)$.

Table 6

Downy mildew incidence on different pearl millet varieties during 1995-1999 at tested locations

\begin{tabular}{lll}
\hline Variety & Mean incidence $(\%)^{\mathrm{a}}$ & Relative variation $^{\mathrm{b}}$ \\
\hline $7042 \mathrm{~S}$ & $78.1 \mathrm{a}$ & $0.58 \mathrm{~b}$ \\
$\mathrm{~J} 104 \mathrm{~S}$ & $61.7 \mathrm{~b}$ & $0.58 \mathrm{~b}$ \\
$5141 \mathrm{~B}$ & $55.7 \mathrm{c}$ & $0.69 \mathrm{a}$ \\
$7042 \mathrm{R}$ & $44.0 \mathrm{~d}$ & $0.65 \mathrm{ab}$ \\
$852 \mathrm{~B}$ & $22.9 \mathrm{e}$ & $0.43 \mathrm{c}$ \\
MBH 110 & $21.2 \mathrm{e}$ & $0.62 \mathrm{ab}$ \\
P 7-4 & $17.3 \mathrm{f}$ & $0.41 \mathrm{c}$ \\
700651 & $15.0 \mathrm{fg}$ & $0.35 \mathrm{c}$ \\
P 310-17 & $14.0 \mathrm{~g}$ & $0.37 \mathrm{c}$ \\
IP 18292 & $13.2 \mathrm{~g}$ & $0.63 \mathrm{ab}$ \\
IP 18293 & $12.8 \mathrm{~g}$ & $0.59 \mathrm{~b}$ \\
\hline
\end{tabular}

${ }^{a}$ Average incidence on the tested line across different locations and over years.

${ }^{\mathrm{b}}$ Relative variation was calculated by dividing standard deviation across locations and over years with the square root of [mean incidence $\times(1-$ mean incidence $)]$.
IP 18293, P 310-17 and 700651 were the most resistant with average downy mildew incidence ranging from $12.8 \%$ to $15.0 \%$ (Table 6 ). Pearl millet lines, $7042 \mathrm{~S}$ and $\mathrm{J} 104 \mathrm{~S}$ were the most susceptible, and recorded an average incidence of $78.1 \%$ and $61.7 \%$, respectively (Table 6). Analyses of the relative variation showed that the variation in the incidence of downy mildew was smaller on certain lines (Table 6), indicating that IP 18292 and IP 18293 may possess resistance only against certain populations of the pathogen, as they varied significantly among locations and over time. In contrast lines 700651 and P 310-17 may possess resistance against a wide range of the pathogen populations with stable resistance across locations and years.

\subsection{Correlation and cluster analyses}

Downy mildew incidence on a few lines was significantly correlated with each other over the locations and years (Table 7). For instance, downy mildew incidence on $\mathrm{P} 7-4$ was positively correlated with those on 852B $(r=0.66)$ and IP $18292(r=0.70)$, and incidence on 7042R correlated with that on IP $18292(r=0.60)$. The significant positively correlated incidence levels suggested that those lines may possess similar resistance gene(s), and therefore, varied similarly over time and locations. The high correlations may also have been due to near-uniform weather conditions rather than the virulence genes in the pathogen population.

Because disease incidence in some lines was positively correlated, principal component analysis was performed to understand the underlying variation patterns in the pathogen population. We then used the 7 principal components derived from this analysis to conduct cluster analysis to group locations. The 17 locations were clustered into six major groups (Fig. 2). Group I included Aurangabad, Coimbatore, Dhule, Mandor, Patancheru, Pune and Hisar; Group II-Jamnagar; Group III-Cinzana, Samanko, and Kamboinse; Group IV_Jodhpur; Group V-Mysore, Durgapura, Sadore

Table 7

Correlation between downy mildew incidence on tested pearl millet lines during 1995-1999

\begin{tabular}{|c|c|c|c|c|c|c|c|c|c|c|c|}
\hline & P7-4 & P310-17 & 700651 & $7042 \mathrm{R}$ & $852 \mathrm{~B}$ & MBH110 & $\mathrm{J} 104 \mathrm{~S}$ & $7042 \mathrm{~S}$ & IP18292 & IP18293 & 5141B \\
\hline P 7-4 & 1.00 & 0.39 & 0.40 & 0.50 & $0.66^{\mathrm{a}}$ & 0.22 & 0.15 & 0.36 & $0.70^{\mathrm{a}}$ & 0.30 & 0.37 \\
\hline P $310-17$ & & 1.00 & 0.27 & 0.34 & 0.40 & 0.22 & 0.12 & 0.25 & 0.24 & 0.25 & 0.18 \\
\hline 700651 & & & 1.00 & 0.00 & 0.45 & 0.07 & 0.41 & 0.21 & 0.22 & 0.10 & 0.32 \\
\hline $7042 \mathrm{R}$ & & & & 1.00 & 0.41 & 0.43 & 0.06 & 0.38 & $0.60^{\mathrm{a}}$ & 0.52 & 0.23 \\
\hline $852 \mathrm{~B}$ & & & & & 1.00 & 0.16 & 0.17 & 0.31 & 0.51 & 0.38 & 0.33 \\
\hline МBН 110 & & & & & & 1.00 & 0.12 & 0.17 & 0.21 & 0.29 & 0.18 \\
\hline J $104 \mathrm{~S}$ & & & & & & & 1.00 & 0.26 & 0.07 & 0.03 & 0.53 \\
\hline $7042 \mathrm{~S}$ & & & & & & & & 1.00 & 0.32 & 0.19 & 0.34 \\
\hline IP 18292 & & & & & & & & & 1.00 & 0.53 & 0.29 \\
\hline IP 18293 & & & & & & & & & & 1.00 & 0.12 \\
\hline 5141B & & & & & & & & & & & 1.00 \\
\hline
\end{tabular}

\footnotetext{
${ }^{\mathrm{a}}$ Significant at $P<0.05$.
} 


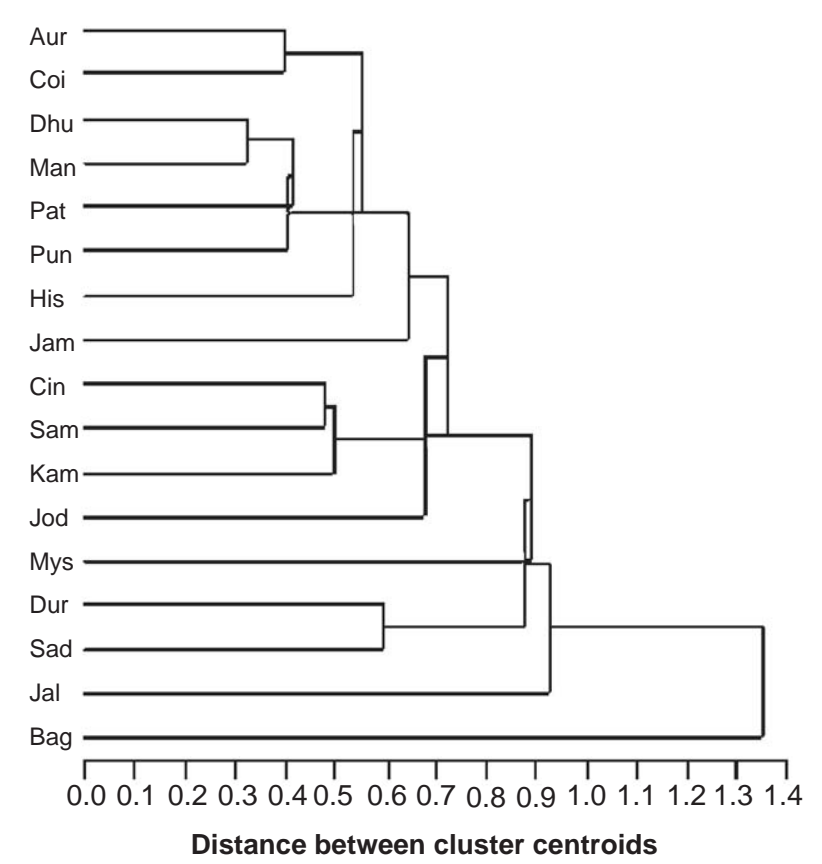

Fig. 2. Grouping of locations using cluster analysis of reduced variables determined by downy mildew incidence levels on pearl millet lines and principal components (Locations: Aur=Aurangabad, Coi $=$ Coimbatore, $\mathrm{Dhu}=$ Dhule, Man $=$ Mandor, Pat $=$ Patancheru, Pun $=$ Pune, His $=$ Hisar, Jam $=$ Jamnagar, Cin $=$ Cinzana, Sam $=$ Samanko, Kam $=$ Kamboinse, Jod $=$ Jodhpur, Mys $=$ Mysore, Dur $=$ Durgapura, $\mathrm{Sad}=$ Sadore, $\mathrm{Jal}=\mathrm{Jalna}, \mathrm{Bag}=$ Bagauda. .

and Jalna and Group VI-Bagauda. Groups I, II, and IV consisted exclusively of locations in India; Groups III and VI exclusively of locations in Africa, and Group V of locations in both India and Africa.

\section{Discussion}

Breeding crop varieties with durable resistance to diseases is made difficult by the variability in the pathogen populations (Christ et al., 1987; Leonard, 1977). Genetic resistance in a cultivar at one location may not function at another location because of the differences in virulence in the pathogen populations (Flor, 1971; Kulkarni and Chopra, 1982; Vanderplank, 1984) or the environmental conditions are such that the resistance is not fully expressed. Differential host varieties are useful in the analysis of pathogen variability at various locations on the basis of clearly visible resistant and susceptible reactions (Vanderplank, 1984; Wolfe and Knott, 1982; Wolfe and Schwarzback, 1975). According to Flors (Flor, 1971) gene-for-gene hypothesis, a series of inbred lines with distinct resistance genes will differentiate discrete races of the pathogen. Theoretically, pathogen populations are composed of numerous strains, each of which exists at certain frequency that describes the probability of encounter (Gale, 1987).
In the case of $S$. graminicola-pearl millet system, the limitation has been the unavailability of well-defined differential lines. Because of the highly heterogeneous and heterozygous nature of pearl millet and highly variable $S$. graminicola populations, it has been difficult to define genes for resistance and genes for virulence in the system. However, there are pearl millet inbred lines that serve as putative differentials to discern the virulence patterns in $S$. graminicola populations to a reasonable level (Thakur, 1995). In the present study, 10 pearl millet inbred lines and an $F_{1}$ hybrid, evaluated in 65 environments (location $\times$ year), provided differential reactions, and the downy mildew incidence on these lines was significantly affected by the location and year. First, the pathogen population may have been different between locations and changed over the years to cause the changes in the relative resistance of the varieties. Furthermore, variance analysis on the standard deviation of incidence among different lines (an indirect measure of the line specificity in pathogen population) also showed significant effects of location and year, suggesting the potential change in the virulence (composition) of the pathogen population. Based on the mapping of quantitative trait loci for downy mildew resistance in pearl millet (Jones et al., 1995) evidence is provided on the existence of differential virulence in the pathogen isolates within Africa, and between Africa and India. The results of this study are consistent with these conclusions and further offer an in-field validation of the earlier study.

Principal component analysis has been used to extract information about the virulence in the pathogen populations from the reaction of multiple differential host lines that may be genetically related to each other. Cluster analysis provides a method for classifying environments or local pathogen populations based on their multiple properties. In this study, the principal component analyses followed by cluster analyses successfully identified several groups within which the frequency of virulence genes in pathogen population was more similar to each other through the study period.

Differences in disease incidence on the variety occur not only because of the innate resistance in a variety, but are also determined by the frequency of virulence gene in pathogen population. Assuming that the pearl millet- $S$. graminicola host-pathosystem is governed by the gene-for-gene hypothesis (Flor, 1971), varieties exposed to pathogen population possessing the matching virulence genes will develop greater disease incidence and severity. Some locations, such as Bagauda in Nigeria and Durgapura in India, had much higher average downy mildew incidence on almost all tested pearl millet lines over the 5 years. This could be either due to the existence of highly virulent pathogen populations at these locations, or the prevailing downy 
mildew-conducive weather conditions. At all locations downy mildew incidence in a highly susceptible line $7042 \mathrm{~S}$ was adequate as an indicative of good disease pressure. Even though a preliminary analysis of the weather variables across these locations over the study period, particularly relative humidity, leaf wetness duration and temperature, indicated that conditions for downy mildew development were fully met (Thakur, unpublished data), the influence of environmental variables on downy mildew incidence cannot be ignored. However, the variations of incidence on tested lines at Bagauda were much higher than at Durgapura suggesting that the pathogen population at Bagauda was highly line-specific, a potential result of directional selection driven by the host varieties grown at this location. The low variation on tested lines at Durgapura, however, could be explained by the potentially diverse and highly virulent pathotypes coexisting in the pathogen population, the pathogen population possessing virulence genes that can overcome the most resistance genes in the tested lines, or the resistance genes in the test lines failing to express at this location during the study period. In contrast, average downy mildew incidence was the lowest at Aurangabad and Coimbatore. Similarly, high and low variations were observed at Aurangabad and Coimbatore, respectively. The most likely explanation for this is that either the pathogen population lacked highly virulent genes (a potential effect of highly susceptible cultivars being grown for a long period) or the low disease incidence at Aurangabad may have been caused by the lower frequency of highly virulence genes in the pathogen population.

Genetic management of downy mildew in pearl millet could be strategically planned using this information on a regular basis, because of a highly dynamic $S$. graminicola-pearl millet system. Downy mildew development is highly influenced by the weather factors, such as relative humidity and temperature, and thus the detailed analysis of weather data over many years in relation to disease incidence would be needed to understand the factors involved in virulence change in the pathogen population. These studies are currently ongoing and will form the basis of another manuscript (Thakur, unpublished).

Pathogenic variability in $S$. graminicola isolates generated from oospores in infected leaf tissues obtained from Burkina Faso, India, Nigeria, Niger and Senegal has been demonstrated (Ball, 1983; Ball and Pike, 1984), and cross compatibility among isolates from different countries and continents was also elucidated (Idris and Ball, 1984). The International Pearl Millet Downy Mildew Nursery (IPMDMN) conducted to test the stability of resistance also provided evidence of variable pathogen populations in countries in Africa and India (Singh, 1995; Singh et al., 1993).
The most resistant pearl millet lines IP 18292 and IP 18293 that were resistant $(<10 \%$ incidence $)$ at 11 of the 17 locations and moderately resistant $(>10 \%)$ at Bagauda, Cinzana, Durgapura, Kamboinse, Mandor and Sadore showed the highest relative variations across locations and years, indicating their resistance is limited to certain downy mildew pathotypes. In contrast, although the average resistance levels of lines 700651 and P 310-17 are slightly lower, these two lines showed much lower variation across different locations and years. Therefore, these two lines are likely to serve as sources of stable resistance in breeding programs. These lines are being used as downy mildew resistance donors in pearl millet hybrid parental line breeding at ICRISAT, India. Lines $7042 \mathrm{~S}$ and $\mathrm{J} 104 \mathrm{~S}$ showed high average susceptibility across locations. When J 104S showed small variations across locations and years, $7042 \mathrm{~S}$ demonstrated modest relative variation, suggesting that this line may possess pathogen-specific resistance gene(s) even though the resistance level is very low for the gene(s), and that $\mathrm{J} 104 \mathrm{~S}$ may not possess specific resistance gene(s).

\section{Acknowledgements}

The authors thank SK Bhatnagar, Coordinator, All India Coordinated Pearl Millet Improvement Project of the Indian Council of Agricultural Research for his keen interest in this research and for encouragement and support to scientists at various Indian locations to conduct the nursery. The technical help received from Research Technicians at various test locations is also duly acknowledged.

\section{References}

Andrews, D.J., 1987. Breeding pearl millet grain hybrids. In: Feistritzer, W.P., Kelly, A.F. (Eds.), Hybrid seed production of selected cereal, oil and vegetable crops. FAO Plant Production and Protection Paper, Vol. 82. Food and Agriculture Organization of the United Nations, Rome, Italy, pp. 83-109.

Ball, S.L., 1983. Pathogenic variability of downy mildew (Sclerospora graminicola) on pearl millet - host cultivar reactions to infection by different pathogen isolates. Ann. Appl. Biol. 102, 257-264.

Ball, S.L., Pike, D.J., 1984. Intercontinental variation in Sclerospora graminicola. Ann. Appl. Biol. 104, 41-51.

Ball, S.L., Pike, D.J., Burridge, C.Y., 1986. Characterization of populations of Sclerospora graminicola. Ann. Appl. Biol. 108, $519-526$.

Bhat, S.S., 1973. Investigations on the biology and control of Sclerospora graminicola on bajra. Ph.D. Thesis. Department of Post Graduate Studies and Research in Botany. University of Mysore, Mysore, India. 165 pp.

Christ, B.J., Person, C.O., Pope, D.D., 1987. The genetic determination of variation in pathogenicity. In: Wolfe, M.S., Caten, C.E. (Eds.), Populations of Plant Pathogens: Their Dynamics and Genetics. Blackwell Scientific, Oxford, UK, pp. 7-19. 
Flor, H.H., 1971. Current status of the gene-for-gene concept. Annu. Rev. Phytopathol. 9, 275-296.

Gale, J.S., 1987. Factors delaying the spread of a virulent mutant of a fungal pathogen: some suggestions from population genetics. In: Wolfe, M.S., Caten, C.E. (Eds.), Populations of the Plant Pathogens: Their Dynamics and Genetics. Blackwell Scientific, Oxford, UK, pp. 55-62.

Hash, C.T., 1997. Research on downy mildew of pearl millet. In: Bantilan, M.C.S., Joshi, P.K. (Eds.), Integrating Research Evaluation Efforts: Proceedings of an International Workshop. 14-16 December 1994. ICRISAT, Patancheru, India, pp. 121-128.

ICRISAT, 1992. Medium term plan1994-1998, Vol. 1, Main Report (mimeographed report), $80 \mathrm{p}$.

Idris, M.O., Ball, S.L., 1984. Inter- and intracontinental sexual compatibility in Sclerospora graminicola. Plant Pathol. 33, 219-223.

Jones, E.S., Liu, C.J., Gale, M.D., Hash, C.T., Witcombe, J.R., 1995. Mapping quantitative trait loci for downy mildew resistance in pearl millet. Theor. Appl. Genet. 91, 448-456.

Kulkarni, R.N., Chopra, V.L., 1982. Environment as the cause of differential interaction between host cultivars and pathogenic races. Letter to the Editor, Phytopathology 72, 1384-1386.

Leonard, K.J., 1977. Selection pressures and plant pathogens. Ann. N.Y. Acad. Sci. 287, 207-222.

Michelmore, R.W., Pawar, M.N., Williams, R.J., 1982. Heterothallism in Sclerospora graminicola. Phytopathology 72, 1368-1372.

Nene, Y.L., Singh, S.D., 1976. Downy mildew and ergot of pearl millet. PANS 22, 366-385.

Sastry, J.G., Ramakrishna, W., Sivaramkrishnan, S., Thakur, R.P., Gupta, V.S., Ranjekar, P.K., 1995. DNA fingerprinting detects genetic variability in the pearl millet downy pathogen (Sclerospora graminicola). Theor. Appl. Genet. 91, 856-861.

Shetty, H.S., Ahmad, R., 1981. Physiologic specialization in Sclerospora graminicola. Indian Phytopathol. 34, 307-309.

Singh, S.D., 1995. Downy mildew of pearl millet. Plant Dis. 79, $545-550$.

Singh, S.D., Singh, G., 1987. Resistance to downy mildew in pearl millet hybrid NHB 3. Indian Phytopathol. 40, 178-180.

Singh, S.D., King, S.B., Werder, J., 1993. Downy mildew disease of pearl millet. Information Bulletin No. 37. International Crops Research Institute for the Semi-Arid Tropics. Patancheru, A.P. 502 324, India.

Singh, S.D., Wilson, J.P., Navi, S.S., Talukdar, B.S., Hess, D.E., Reddy, K.N., 1997. Screening techniques and sources of resistance to downy mildew and rust in pearl millet. Information Bulletin No. 48. International Crops Research Institute for the Semi-Arid Tropics: Patancheru, A.P. 502 324, India.

Thakur, R.P., 1995. Status of international sorghum anthracnose and pearl millet downy mildew virulence nurseries. In: Leslie, J.F., Frederiksen, R.A. (Eds.), Disease Analysis through Genetics and Biotechnology: Interdisciplinary Bridges to Improve Sorghum and Millet Crops. Iowa State University Press, Ames. USA, pp. 75-92.

Thakur, R.P., Rao, V.P., 1997. Variation in virulence and aggressiveness among pathotypes of Sclerospora graminicola on pearl millet. Indian Phytopathol. 50, 41-47.

Thakur, R.P., Shetty, K.G., 1993. Variation in pathogenicity among single-oospore isolates of Sclerospora graminicola, the causal organism of downy mildew in pearl millet. Plant Pathol. 42, 715-721.

Thakur, R.P., Shetty, K.G., King, S.B., 1992. Selection for hostspecific virulence in asexual populations of Sclerospora graminicola. Plant Pathol. 41, 626-632.

Thakur, R.P., Pushpavathi, B., Rao, V.P., 1998a. Virulence characterization of single-zoospore isolates of Sclerospora graminicola from pearl millet. Plant Dis. 82, 747-751.

Thakur, R.P., Rao, V.P., Hash, C.T., 1998b. A highly virulent pathotypes of Sclerospora graminicola from Jodhpur, Rajasthan, India. Int. Sorghum Millets Newsl. 39, 140-142.

Thakur, R.P., Rao, V.P., Sastry, J.G., Sivaramakrishnan, S., Amruthesh, K.N., Barbind, L.D., 1999. Evidence for a new virulent pathotypes of Sclerospora graminicola on pearl millet. J. Mycol. Plant Pathol. 29, 61-69.

Vanderplank, J.E., 1984. Disease Resistance in Plants, 2nd Edition. Academic Press, Orlando.

Werder, J., Ball, S.L., 1992. Variability of pearl millet downy mildew (Sclerospora graminicola) and its implications for breeding for stable and durable resistance. Tropical Pest Manage. 38, 43-47.

Williams, R.J., 1984. Downy mildews of tropical cereals. Adv. Plant Pathol. 2, 1-103.

Williams, R.J., Singh, S.D., Pawar, M.N., 1981. An improved field screening technique for downy mildew resistance in pearl millet. Plant Dis. 65, 239-241.

Wolfe, M.S., Knott, D.R., 1982. Population of plant pathogens: some constraints on analysis of variation in pathogenicity. Plant Pathol. 31, 79-90.

Wolfe, M.S., Schwarzback, E., 1975. The use of virulence analysis in cereal mildews. Phytopath. Z. 82, 297-307. 